\title{
Fully Softened and Residual Shear Strengths of Midra Shale
}

\author{
Hisham Eid \\ heid@qu.edu.qa \\ Department of Civil and Architectural Engineering, Qatar University, Doha, Qatar
}

\begin{abstract}
This paper presents a comparison of the fully softened shear strengths measured using the triaxial and torsional ring shear devices for a shale that possesses noticeably high plasticity and induration. The residual shear strength measured using the torsional ring shear device was also introduced for a supplementary comparison. It was shown that the mode of shear (e.g., the triaxial mode or the torsional ring mode) slightly affects the measured fully softened shear strength of Midra shale. The fully softened strength failure envelopes associated with the two shearing modes exhibit a moderate degree of nonlinearity that is in turn higher than that of the residual shear strength envelope. The measured classification indices of Midra shale are significantly sensitive to the sample preparation procedure. As a result, care should be taken when predicting the fully softened and residual shear strengths of Midra shale using relationships that correlate shear strength to such indices.
\end{abstract}

Keywords: Failure envelope; Fully softened strength; Residual strength; Shear strength; Shale

\section{INTRODUCTION}

Layers of Midra shale are frequently encountered in subsurface investigations of construction projects in Doha, capital of Qatar. The shale usually interrupts a continuous layer of fractured limestone (Figure 1). Midra shale is a highly indurated attapulgitic clay and silty material. The percentage of clay varies with the project site location and consequently changes the shale plasticity and colour. In most of these locations, the shale is light green to gray and has a clay-size fraction (i.e., quantity of particles smaller than $0.002 \mathrm{~mm}$ ) higher than $50 \%$.

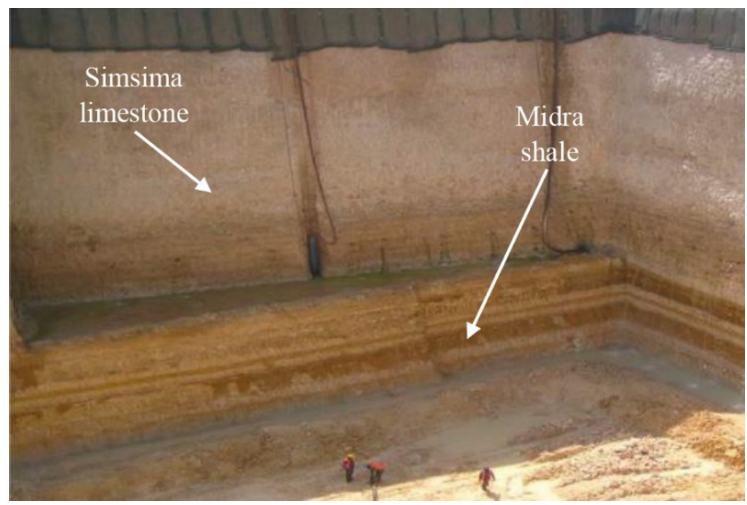

Figure 1: Vertical cut showing the subsurface stratification at one of construction sites in Doha 
Because of its high induration, Midra shale has been dealt with, by most of practitioners, as a rock. Consequently, they only measure and report its physical properties, rock quality indices (e.g., RQD), unconfined compressive strength, and modulus of elasticity. Shear strength that controls friction along the cracks of Midra shale (i.e., the fully softened strength) as well as its strength that is mobilized at large displacements (i.e., the residual strength) are usually not measured. Instead, these strengths are typically predicted using published relationships that correlate shear strength to soil classification indices such as the liquid limit, plasticity index, and clay-size fraction. It is commonly known that the fully softened and residual shear strengths are directly relevant to stability assessment of anchor walls, nailed excavations, and slopes.

The measured classification indices of Midra shale are significantly sensitive to the sample preparation procedure due to the material induration. For example, following the standard sample preparation procedures described in ASTM D4318 (1999a) and ASTM D422 (1999b), liquid limit, plastic limit, and clay-size fraction of $158 \%, 67 \%$, and $63 \%$, respectively, were measured. On the other hand, liquid limit, plastic limit and clay-size fraction of $231 \%, 74 \%$, and $79 \%$, respectively, were measured when the disaggregation of Midra shale particles was maximized through ball-milling until the entire sample passes the U.S. standard sieve No. 200. Such change in the measured classification indices was also experienced for Oahe Firm shale utilizing the facilities of the soil mechanics lab at Qatar University to have ASTM derived liquid limit, plastic limit, and clay-size fraction of $97 \%, 40 \%$, and $52 \%$ and ball-milled derived values of $140 \%, 41 \%$, and $79 \%$, respectively. Similar ball-milling derived classification indices were measured for Oahe firm shale by Stark and Eid (1994) utilizing the facilities of the soil mechanics lab at the University of Illinois at Urbana-Champaign. This similarity supports the sensitivity of the measured classification indices of Midra shale to the sample preparation procedure. The factors influencing determination of shale classification indices and their correlation to shear strength properties were comprehensively presented in the literature by the author of this paper (e.g., Eid 2001 and 2006; Eid et al. 2016; Eid and Rabie 2017).

\section{TESTING METHODS AND RESULTS}

Three consolidated drained triaxial compression tests and seven torsional ring shear tests were performed on normally consolidated remoulded specimens of Midra shale to determine the fully softened shear strength. Triaxial tests were conducted at consolidation stresses $\left(\sigma_{3}^{\prime}\right)$ of 60,120 , and $240 \mathrm{kPa}$ following the procedure described in ASTM D7181-11 (2011). The ring shear tests were conducted at effective normal stresses of 10, 25, 50, 100, 200,300, and $400 \mathrm{kPa}$ as described in Eid and Rabie (2017) and ASTM D7608-10 (2010). The residual shear strength was determined using a ring shear remoulded specimen overconsolidated and presheared at $700 \mathrm{kPa}$. The multistage shearing process as described in Stark and Eid (1993 and 1994) and ASTM D6467 (1999c) was followed for shear testing at the seven lower effective normal stresses.

Figure 2 shows the shear strengths measured using the torsional ring shear device and their associated failure envelopes. It can be seen that the fully softened friction angle measured for such mode of shear ranges between $18.8^{\circ}$ and $12.8^{\circ}$ at effective normal stress of 10 and $400 \mathrm{kPa}$, respectively. Less than half of these values were measured for residual friction angles at the same effective normal stresses. 
Mohr's circles yielded from the three triaxial compression tests conducted on different remoulded specimens of Midra shale are shown in Figure 3. The corresponding fully softened shear strength failure envelope for such mode of shear is developed and presented on the same figure. It can be seen that the curvature of this envelope is almost similar to that of the fully softened strength envelope developed using the ring shear test results. However, the triaxial shear mode seems to yield slightly higher strength values.

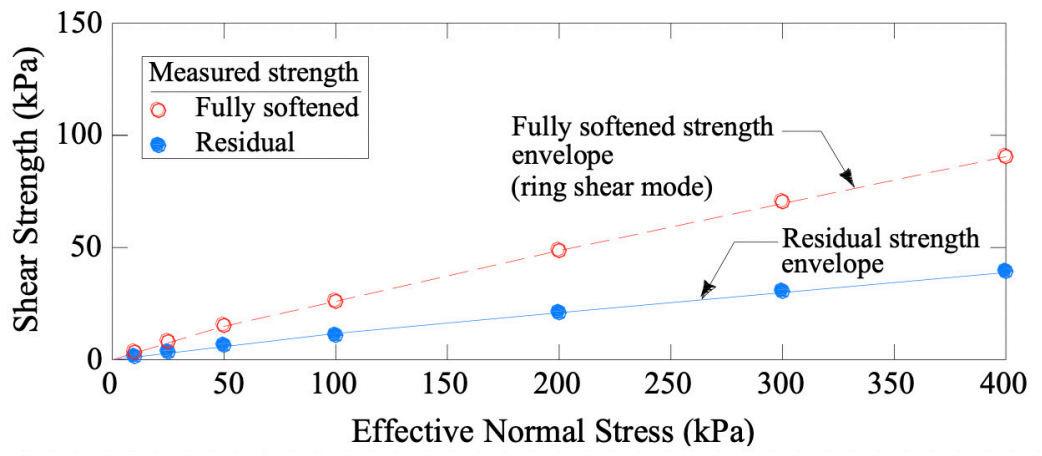

Figure 2: Shear strength of Midra shale based on the results of torsional ring shear tests

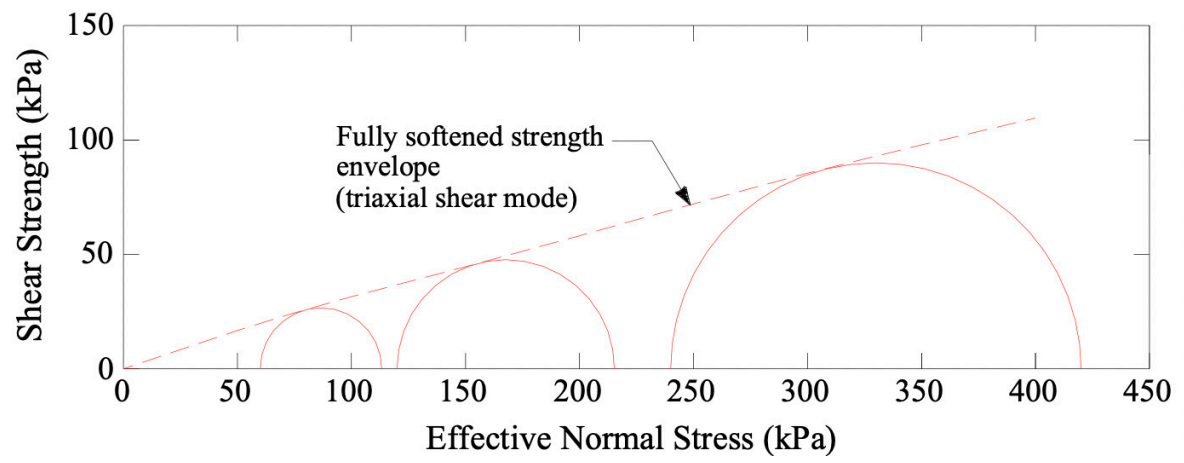

Figure 3: Fully softened shear strength of Midra shale based on the results of triaxial compression tests on remoulded specimens

\section{ANALYSIS AND CONCLUSIONS}

As shown in Figure 2, Midra shale exhibits a significant difference between the fully softened strength and residual strength. The difference decreases with increasing the effective normal stress. This reveals that the fully softened shear strength failure envelope has a larger nonlinearity than the drained residual failure envelope. A similar behaviour was reported and interpreted by Stark and Eid (1997) for several plastic soils.

In practice, residual shear strength envelopes of soils are frequently considered as straight lines that go to the origin of the shear strength versus effective normal stress plot. As a result, the residual shear strength can be simply expressed in terms of one friction angle. If such practice is applied to the residual strength data presented in Figure 2, an average residual friction angle of $6.5^{\circ}$ can be assigned to Midra shale. Such significantly low friction angle reflects the shale mineralogical composition and mandates having an 
extra care in stability assessments that involve dealing with large displacements along Midra shale.

A comparison was made between the fully softened angles obtained from the consolidated drained triaxial compression tests $\left(\phi_{\mathrm{fs}}^{\prime}\right)_{\text {tri }}$, and drained torsional ring shear tests $\left(\phi_{\mathrm{fs}}^{\prime}\right)_{\text {ring }}$ as shown in Figure 4. The nonlinear failure envelope shown in Figure 3 was used to estimate $\left(\phi_{\mathrm{fs}}^{\prime}\right)_{\text {tri }}$ at effective normal stresses of $100,200,300$, and $400 \mathrm{kPa}$ for comparison with $\left(\phi_{\mathrm{fs}}^{\prime}\right)_{\text {ring }}$ measured at the same effective stresses.

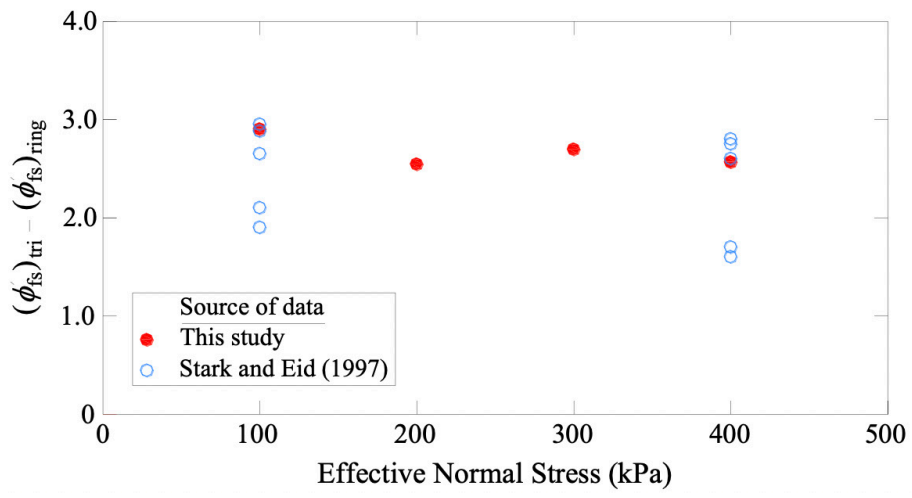

Figure 4: Comparison of fully softened friction angles obtained for different modes of shear

Figure 4 shows that the triaxial compression tests on Midra shale yields a fully softened friction angle that is approximately $2.5^{\circ}$ to $2.9^{\circ}$ higher than that obtained from the torsional ring shear test. The results of this study are in agreement with the data published in Stark and Eid (1997) showing that the average difference between $\left(\phi_{\mathrm{fs}}^{\prime}\right)_{\text {tri }}$ and $\left(\phi_{\mathrm{fs}}^{\prime}\right)_{\text {ring }}$ is about $2.5^{\circ}$. This difference is attributed to the effect of the shear mode that should be considered by the designers for simulating the mode that would be developed in the field with that of the shear tests.

\section{REFERENCES}

ASTM. (1999a). "Standard test method for liquid limit, plastic limit, and plasticity index of soils.” D4318, Annual Book of ASTM Standards, West Conshohocken, PA, 526-538.

ASTM. (1999b). "Standard test method for particle-size analysis of soils." D422, Annual Book of ASTM Standards, West Conshohocken, PA.

ASTM. (1999c). "Standard test method for torsional ring shear test to determine drained residual shear strength of cohesive soils." D6467, Annual Book of ASTM Standards, West Conshohocken, PA.

ASTM. (2010). "Standard test method for torsional ring shear test to determine drained fully softened shear strength and nonlinear strength envelope of cohesive soils (using normally consolidated specimen) for slopes with no preexisting shear surfaces." D7608-10, Annual Book of ASTM Standards, West Conshohocken, PA.

ASTM. (2011). "Method for consolidated drained triaxial compression test for soils." D7181-11, Annual Book of ASTM Standards, West Conshohocken, PA. 
Eid, H.T. (2001). "Correlation between Shale Index Properties Derived from Different Sample Preparation Procedures." Proceedings of the $15^{\text {th }}$ International Conference on Soil Mechanics and Geotechnical Engineering, Istanbul, Turkey, Vol. 1, pp. 77-80.

Eid, H.T. (2006). "Factors influencing determination of shale classification indices and their correlation to mechanical properties." Geotechnical and Geological Engineering Journal, Vol. 24, No. 6 , pp. 1695-1713.

Eid, H.T., Rabie, K.H., and Wijewickreme, D. (2016). "Drained residual shear strength at effective normal stresses relevant to soil slope stability analyses." Engineering Geology, Vol. 204, pp. 94-107

Eid, H.T., and Rabie, K.H. (2017). "Fully softened shear strength for soil slope stability analyses." International Journal of Geomechanics, ASCE, Vol. 17, Issue 1, 04016023-1 to10.

Stark, T.D., and Eid, H.T. (1993). "Modified Bromhead ring shear apparatus." Geotechnical Testing Journal, ASTM, Vol. 16, No. 1, pp. 100-107.

Stark, T.D., and Eid, H.T. (1994). "Drained residual strength of cohesive soils." Journal of Geotechnical Engineering, ASCE, Vol. 120, No. 5, pp. 856-871.

Stark, T.D., and Eid, H.T. (1997). "Slope stability analyses in stiff fissured clays." Journal of Geotechnical and geoenvironmental Engineering, ASCE, Vol. 123, No. 4, pp. 335-343. 